\title{
KAJIAN KARBON PADA PENGEMBANGAN PRODUK UNGGULAN BUAH- BUAHAN RAMAH LINGKUNGAN DI KABUPATEN TUBAN JAWA TIMUR
}

\author{
${ }^{1)}$ Kristiawan ${ }^{2)}$ Maimunah \\ Fakultas Pertanian Universitas Sunan Bonang Tuban
}

\begin{abstract}
The determination of national and regional leading commodities is the first step towards agricultural development that is based on the concept of efficiency to achieve comparative and competitive advantage in the face of trade globalization. Commodity development that has a comparative advantage in terms of supply is characterized by its superiority in its growth in the biophysical, technological, and socio-economic conditions of farmers in a region. This is important because changes in the external environment through the process of globalization require local governments (provincial / district / city) to increase their competitiveness, so they are able to compete globally. The agricultural commodities in the GRDP structure contribute significantly to the economy in Tuban Regency. The purpose of this study is to describe the typolology of the leading producer of environmentally friendly fruit commodities based on land suitability, determine environmentally friendly superior commodities for fruits in Tuban Regency, analyzing the optimization of the farm management of the development of superior commodities of environmentally friendly fruits in Tuban. Quantitative analysis used in this study is the analysis of regional economic structures using the Location Quotient (LQ) approach, which is the approach used to determine the commodity in an area includes a base or non basis based on harvested area or quantity of production each year. While environmental aspects are approached through the calculation of biomass and carbon content and $\mathrm{CO} 2$ uptake of friendly superior fruit crops environment. The results of the study based on the Location Quotient (LQ) method show that the potential of star fruit, red guava and mango commodities in Tuban is classified as base, while citrus fruit is classified as non-base. Socially viable farming based on employment is star fruit farming and economically viable based on income is mango fruit farming and environmentally viable based on carbon biomass is mango fruit farming. Whereas socially, economically and environmentally viable farming is mango fruit. Based on the calculation of carbon biomass, the largest carbon biomass is obtained from mango fruit plants in the amount of $61,823.20 \mathrm{~kg} / \mathrm{ha}$. This is because the mango fruit plant has a larger stem than other commodity crops such as star fruit, red guava or orange. In addition, mango commodity plants have a relatively long age so that it has a relatively large carbon biomass. Besides being influenced by plants themselves, carbon biomass that is formed can also be influenced by quality in land management.
\end{abstract}

\section{Keywords: Superior commudity, Biomassa Carbon, Analysis LQ}

\section{PENDAHULUAN}

Indonesia diketahui mempunyai keanekaragaman jenis buah-buahan yang tertinggi di dunia, namun pada pasar domestrik dibanjiri dengan buah-buahan impor yang berasal dari negeri subtropis. Di pasaran lokal didominasi dengan buah-buahan yang berasal dari Thailand, Cina, dan Australia, diantaranya sudah begitu dikenal, sedangkan buah-buahan tropis asal negeri sendiri tenggelam. Buah tropis yang diunggulkan Indonesia dan dirisetkan pengembangannya oleh Dinas Pertanian adalah Pisang, Manggis, Nenas, Pepaya dan Salak. Jurnal Biodiversitas (2007) menyatakan keragaman jenis buah-buahan asli Indonesia dan potensinya. Jenis buah-buahan tersebut adalah: Durian, Mangga, Rambutan, Salak, Manggis, Duku, Buah Merah dan Matoa. Hasil Sensus Pertanian tahun 2013, menunjukkan bahwa jumlah rumah tangga tanaman buah-buahan mencapai 2,2 juta rumah tangga dan menempati ketiga setelah subsektor tanaman pangan dan subsektor perikanan. Besarnya jumlah rumah tangga buah-buahan menunjukkan bahwa subsektor 
ini berperan strategis dalam peningkatan pendapatan masyarakat, dan percepatan penurunan angka kemiskinan di dalam negeri.

Kabupaten Tuban merupakan salah satu Kabupaten di Provinsi Jawa Timur yang membutuhan proses percepatan dalam membangun ekonomi untuk dapat membangun masyarakat yang sejahtera sehingga tidak tertinggal dengan wilayah lain, sesuai dengan yang telah diamanatkan dalam RPJMD (Rencana Pembangunan Jangka Menengah Daerah) Kabupaten Tuban. Salah satu potensinya yaitu pada sektor pertanian. Sektor pertanian dalam arti luas meliputi sektor produksi berbagai komoditi selain tanaman bahan makanan (TBM) yaitu tanaman buah-buahan, tanaman perkebunan, perikanan dan tanaman biofarma serta tanaman hias. Tanaman buah-buahan semusim yang utama di Kabupaten Tuban adalah melon, semangka dan blewah. Sedangkan tanaman sayuran semusim yang utama di Kabupaten Tuban adalah bawang merah, cabe besar, cabe rawit, terong, tomat, kangkung, bayam dan sawi. Pada tanaman buah-buahan tahunan yang utama di Kabupaten Tuban jenisnya lebih banyak antara lain alpukat, belimbing, duku, jambu biji, jambu air, jeruk siam atau dengan nama lain jeruk keprok, mangga, nangka, pepaya, pisang, sawo, sirsak dan sukun. Beberapa buah-buahan lain yang hanya terdapat di kecamatan tertentu, yaitu buah nenas, durian, dan anggur. Sawo, mangga dan pepaya merupakan jenis buah yang terdapat di semua kecamatan.

Pengembangan produk buah-buahan unggulan yang ramah lingkungan harus mempertimbangkan aspek lingkungan, yaitu kualitas agroekologinya. Artinya dalam pengembangan produk tersebut dalam kerangka pembangunan pertanian berkelanjutan (sustainable farming development). Dengan mengacu pada Permentan RI Nomor 64 Tahun 2013 tentang Sistem Pertanian Organik, pengembangan produk unggulan juga dapat dilaksanakan dengan cara organik. Sehingga selain dapat meningkatkan pendapatan petani buah-buahan, produk buah-buahan organik juga mampu meningkatkan kualitas agroekologi lahan yang digunakan. Selain itu kualitas hasil panennya lebih sehat karena tidak mengandung residu pupuk kimiawi dan pestisida yang mengandung racun. Produk buah-buahan terdiri dari sayuran, buah-buahan, tanaman hias dan tanaman rempahrempah atau empon-empon. Buah-buahan merupakan komoditi yang memiliki nilai ekonomi paling tinggi dan prospektif diantara komoditi buah-buahan. Hasil penelitian ini diharapkan dapat memberikan dasar pemikiran yang ilmiah dan kuat bagi upaya-upaya pemerintah dalam meningkatkan pertumbuhan ekonomi daerah, yaitu meningkatkan kontribusi dari sektor pertanian Kabupaten Tuban.

\section{Produk Unggulan Daerah}

\section{TINJAUAN PUSTAKA}

Produk unggulan daerah (PUD) di Indonesia sejak lama didasarkan atas peraturan pemerintah, seperti dikutip oleh Riza Alfita (2009), bahwa Produk Unggulan Daerah (PUD) adalah suatu produk unggulan yang memiliki ciri khas dan keunikan tersendiri dan berbeda dengan yang dimiliki oleh daerah lain memiliki daya saing tinggi serta mampu memberikan peluang kesempatan kerja untuk masyarakat lokal. Produk unggulan daerah juga berorientasi ramah lingkungan dan berorientasi pada pasar lokal maupun nasional serta regional. Pengembangan produk unggulan dan pemberdayaan sebagai potensi ekonomi daerah pada era otonomi merupakan suatu pekerjaan yang sulit dilaksanakan, hal ini karena keterkaitan erat dengan kemauan politik ataupun kebijakan dari pemerintah yang berpengaruh terhadap pengembangan PUD. Dalam pengembangan serta pemberdayaan produk unggulan daerah sebagai salah satu tonggak dari pada ekonomi daerah maka diperlukannya peranan pemerintah daerah.

Menurut Sri (2010), komoditi merupakan suatu produk yang dihasilkan secara bertahap oleh produsen. Komoditi dikatakan unggulan apabila mempunyai kontribusi yang besar minimal untuk produsen itu sendiri. Ada beberapa cara dalam menentukan sebuah komoditi unggulan. Berikut ini adalah pendekatan yang dilakukan untuk menentukan suatu komoditi yang dikatakan unggul bagi suatu daerah, yaitu : 
(1) Value Added, yaitu nilai tambah cukup besar dari total outputnya, yaitu di atas ratarata dari nilai tambah seluruh kegiatan perekonomian regional.

(2) Input Domestic, kandungan input domestik besar, di atas rata-rata total dari input domestik seluruh kegiatan ekonomi.

(3) Spesialisasi Ekspor, peran suatu industri dalam ekspor netto (baik antar propinsi dan Negara) cukup besar, diatas rata-rata.

(4) Investasi/output, peran suatu industry dalam pembentukan investasi cukup besar (diatas rata-rata).

(5) Penyebaran (forward linkages), indeks penyebaran besar lebih dari 1, yang merupakan keterkaitan ke depan atau serapan terhadap output sektor industri.

(6) Kepekaan (Backward Lingkages), indeks kepekaan besar lebih dari 1, yang merupakan keterkaitan ke belakang atau kemampuan sektor industri untuk menyerap output dari beberapa usaha.

(7) Kontribusi terhadap perekonomian (PDRB), peran produk terhadap pembentukan PDRB yang cukup tinggi di atas, rata-rata peran seluruh usaha perekonomian daerah.

Menurut Huseini (1999), produk unggulan merupakan produk yang memberikan nilai tambah serta sumbangan pemasukan tertinggi pada suatu perekonomian daerah. Pemasukan ini berdasarkan pada aspek nilai dan kontribusi suatu komoditas atau produk. Dikatakan sebagai produk unggul apabila produk tersebut dapat memberikan nilai tambah yang tinggi sepanjang rantai nilai dan memberikan kontribusi terbesar dari suatu perekonomian daerah. Pendekatan pohon industri dan rantai nilai (value chain) merupakan analisa pendekatan yang digunakan untuk mengetahui produk yang memberikan nilai tambah.

Komoditi unggulan adalah hasil usaha masyarakat yang mempunyai kesempatan dalam mencapai pemasaran yang tinggi serta memberikan keuntungan untuk masyarakat. Komoditi unggulan memiliki beberapa kriteria yaitu :

a. Memiliki daya saing tinggi di pasaran (keunikan atau ciri spesifik, kualitas bagus, harga murah);

b. Memanfaatkan potensi sumberdaya lokal yang berpotensial untuk dikembangkan;

c. Memiliki nilai tambah bagi masyarakat;

d. Secara ekonomi memberikan keuntungan dan bermanfaat dalam meningkatkan pendapatan serta kemampuan sumberdaya manusia;

e. Patut mendapatkan dukungan dari modal bantuan atau kredit

Komoditas unggulan dalam pemasaran dicirikan dengan produk handal yang dihasilkan oleh daerah tertentu yang diduga memiliki keunggulan yang khas, sehingga memiliki daya saing yang kuat. Keunggulan tersebut antara lain iklim yang cocok, lahan subur, tenaga kerja terampil dan manajemen yang efisien serta penerapan teknologi. Keunggulan tersebut disebutkan sebagai keunggulan komparatif (comparative advantage). Upaya pengembangan komoditas unggulan dapat dilakukan dengan :

(1) Program pengembangan investasi dalam rangka peningkatan industrialisasi di daerah baik pengembangan industri mikro/kecil, kerajinan, agro industri maupun pengembangan agropolitan untuk pengembangan agro industri terpadu dengan pengembangan pusat-pusat pertumbuhan ekonomi wilayah.

(2) Mengembangkan promosi dan untuk pengenalan komoditas unggulan, andalan dan potensial agar dapat menjangkau pasar yang lebih luas.

(3) Kerjasama dengan multipihak dalam pengelolaan usaha dalam peningkatan produk dan jangkauan pasar komoditas yang lebih luas.

Pentingnya komoditas unggulan berkaitan erat dengan dua konsep pembangunan perekonomian yaitu konsep Kompetensi Inti (Core Competency) dan konsep Daya Saing Daerah. Pembangunan kompetensi inti pada dasarnya terbentuk atas dasar produk atau komoditas unggulan, namun tidak semua komoditas unggulan bisa dijadikan suatu 
kompetensi inti pada suatu daerah. Hal ini dikarenakan kompetensi inti bukan berasal dari produk unggulan daerah tersebut, melainkan dari kompetensi inti daerah itu sendiri. Karena kompetensi inti memiliki pengertian yang lebih detail dan luas daripada produk atau komoditas unggulan.

\section{Biomassa Karbon}

Pohon mempunyai kemampuan untuk melakukan fotosintesis, proses fotosintesis pohon membutuhkan gas $\mathrm{CO}_{2}$ sebagai bahan bakunya dan hasil fotosintesis tersebut berupa oksigen dan zat-zat makanan yang diperlukan oleh pohon atau tumbuhan dan makhluk hidup yang lain. Kemampuan pohon dalam menyerap karbondioksida membutuhkan stomata yang memungkinkan masuknya $\mathrm{CO}_{2}$. Purwaningsih (2007) memaparkan bahwa pengukuran serapan karbondioksida dapat dilakukan dengan metode karbohidrat, karena jumlah massa karbondioksida dalam proses fotosintesis berbanding lurus dengan jumlah karbon dalam karbohidrat. Selama kurun waktu 40 tahun dalam proses pengelolaan dan pemanfaatan sumberdaya hutan di Indonesia, telah menyebabkan terjadinya kerusakan hutan (degradasi dan deforestasi). Faktor - faktor utama dalam mempercepat terjadinya degradasi dan deforestasi di Indonesia yaitu kegiatan eksploitasi hutan secara legal maupun ilegal, konversi hutan alam dan gambut untuk dijadikan perkebunan sawit serta pertambangan, pemberian ijin pemanfaatan kayu, serta kebakaran hutan (FWI, 2001).

Pemicu terjadinya pelepasan karbon dalam jumlah besar ke atmosfer yaitu kegiatan konversi hutan. Terlepasnya Biomassa Karbon dalam biomassa tumbuhan dan memicu terjadinya degradasi tanah yang menyebabkan terlepasnya karbon dari bahan organik tanah merupakan dampak dari konversi hutan. Perubahan vegetasi penutup lahan juga menyebabkan tidak terjadinya proses penyerapan karbon sehingga yang terjadi bukan hanya pelepasan Biomassa Karbon di hutan namun juga hilangnya fungsi penyerapan karbon oleh hutan. Hal yang sama terjadi dalam proses degradasi hutan. Penyebab berkurangnya kandungan karbon dalam tutupan hutan dan turut berkurangnya fungsi penyerapan karbon oleh hutan dikarenakan berkurangnya vegetasi hutan. Dalam penutupan lahan hutan menjadi kawasan budidaya pertanian, proses fotosintesis yang terjadi dapat mengimbangi proses fotosintesis pada lahan hutan namun serapan karbon tanaman budidaya pertanian tidak sebesar serapan karbon tanaman hutan. Pohon di hutan mampu menyerap $\mathrm{CO}_{2}$ sebagai proses fotosintesis dan menyimpannya dalam bentuk karbohidrat pada kantong karbon yang terdapat di daun, batang dan akar sebelum dilepaskan kembali ke atmosfer. Sehingga menimbulkan hubungan antara biomassa hutan dengan kandungan karbon. Terdapat empat kolam karbon pada hutan; biomassa atas permukaan (aboveground biomass), biomassa bawah permukaan (undergroundbiomass), kandungan karbon organik tanah, serta bahan organik mati. Semua komponen vegetasi hutan yang terdiri dari pohon dan strata tumbuhan bawah termasuk dalam biomassa permukaan. Sedangkan akar merupakan biomassa bawah permukaan selain kandungan organik tanah yang mempunyai kelas tersendiri dalam perhitungan carbon pools. Serasah dan kayu mati yang telah ditetapkan berdasarkan tingkat dekomposisi termasuk dalam bahan organik mati.

\section{Karbon (C)}

Dalam siklus karbon, vegetasi melalui fotosistesis merubah $\mathrm{CO}_{2}$ dari udara dan air menghasilkan karbohidrat dan oksigen. Karbohidrat yang terbentuk disimpan oleh vegetasi dan sebagian oksigen dilepaskan ke atmosfer (Fardiaz 1995). Menurut Whitmore (1985) umumnya karbon menyusun 45-50\% berat kering dari biomassa.

Menurut Dury et al., (2002) dalam Ginoga (2004), dalam tegakan hutan karbon terdapat pada:

a. Pohon dan akar (Tr), yaitu pada biomassa hidup baik yang terdapat di atas permukaan tanah atau di bawah permukaan dari berbagai jenis pohon, termasuk akar, batang, 
daun, dan cabang;

b. Vegetasi lain (OV), yaitu pada vegetasi bukan pohon (semak, belukar, herba, dan rerumputan);

c. Sampah hutan, yaitu pada biomassa mati di atas lantai hutan, termasuk sisa pemanenan; dan

d. Tanah (S), yaitu pada karbon tersimpan dalam bahan organik (humus) maupun dalam bentuk mineral karbon. Karbon dalam tanah mungkin mengalami peningkatan atau penurunan tergantung pada kondisi tempat sebelumnya dan kondisi pengolahan.

Dalam inventarisasi karbon hutan, karbon pool (kantung karbon) yang diperhitungkan setidaknya ada 4 kantung karbon. Kantong karbon merupakan wadah dengan kapasitas untuk menyimpan karbon dan melepaskannya. Keempat kantong karbon tersebut adalah biomassa atas permukaan, biomassa bawah permukaan, bahan organik mati dan karbon organik tanah. Berdasarkan keberadaannya di alam, komponen karbon dapat dibedakan menjadi 2 kelompok yaitu karbon di atas permukaan tanah dan karbon di dalam tanah.

Biomassa pohon merupakan semacam material yang hidup di atas permukaan tanah. Batang, cabang, tunggul, kulit kayu, biji serta daun dari vegetasi baik dari strata pohon maupun strata tumbuhan bawah di lantai hutan merupakan bagian dari katong karbon di permukaan. Biomassa tumbuhan bawah merupakan biomassa yang berasal dari akar tumbuhan. Pengertian akar ini berlaku hingga ukuran diameter tertentu yang telah ditetapkan. Hal ini dilakukan karena diameter akar tumbuhan yang lebih kecil dari ketentuan cenderung sulit untuk dibedakan dengan bahan organik tanah dan serasah. Nekromasa meliputi akar mati, kayu mati dan tunggul dengan batang pohon mati baik yang masih tegak atau telah tumbang dan tergeletak di permukaan tanah yang merupakan komponen penting dari karbon dan harus diukur pula agar diperoleh estimasi Biomassa Karbon yang akurat.

Pada biomassa akar, Akar akan menyalurkan langsung jumlah karbon yang sangat besar kedalam tanah, dan cukup lama keberadaannya di dalam tanah. Akar-akar besar (diameter $>2 \mathrm{~mm}$ ) akan mendominasi biomassa akar di tanah hutan, sedangkan akar-akar halus yang lebih pendek daur hidupnya akan mendominasi pada tanah pertanian. mengestimasi Biomasa akar yang didasarkan pada diameter akar (akar utama), sama halnya cara untuk mengestimasi biomasa pohon yang didasarkan pada diameter batang. Bahan organik tanah yaitu bahan yang berasal dari sisa tanaman, hewan serta manusia yang terdapat pada permukaan maupun di dalam tanah, yang sebagian atau seluruhnya dirombak oleh organisme tanah sehingga melapuk dan tercampur dengan tanah.

\section{Biomassa}

Definisi dari Biomassa yaitu jumlah total materi yang hidup di atas permukaan pada suatu pohon serta dinyatakan dengan satuan ton berat kering per satuan luas (Brown, 1997). Berat bahan vegetasi yang hidup pada bagian atas maupun bawah permukaan tanah dalam waktu tertentu disebut dengan Biomassa vegetasi (Roberts et al., 1993). Dalam pendugaan potensi serapan karbon yang tersimpan dalam vegetasi hutan karena 50\% biomassa tersusun oleh karbon maka bisa menggunakan biomassa hutan (Brown, 1997). Penyusun utama Biomassa yaitu senyawa karbohidrat yang tersusun dari unsur karbon dioksida, oksigen, dan hidrogen. Umur tegakan hutan, sejarah perkembangan vegetasi serta komposisi dan struktur tegakan mempengaruhi Biomassa tegakan (Lugo dan Snedaker, 1974 dalam Kusmana, 1992).

\section{Karbon Hutan}

Biomassa hutan sangat selaras dengan isu perubahan iklim. Biomasa hutan mempunyai peran penting dalam siklus biogeokimia terutama dalam siklus karbon. Keseluruhan karbon hutan, sekitar 50\% diantaranya tersimpan dalam vegetasi hutan. Peningkatan jumlah karbon di atmosfer dikarenakan terjadinya kerusakan hutan, 
pembalakan kebakaran dan sebagainya. Siklus karbon secara sederhana dapat menjelaskan tentang dinamika karbon di alam. Siklus karbon yaitu siklus biogeokimia yang meliputi pertukaran atau perpindahan karbon diantara biosfer, pedosfer, geosfer, hidrosfer dan atmosfer bumi. Siklus karbon sebenarnya merupakan suatu proses yang sulit serta dalam setiap proses saling memberikan pengaruh terhadap proses lainnya. Tanah, Hutan, laut dan atmosfer semuanya menyimpan karbon yang akan berpindah secara dinamis dari tempat-tempat penyimpanan tersebut sepanjang waktu.Tempat penyimpanan ini disebut dengan kantong karbon aktif (active carbon pool).

Deposit bahan bakar fosil merupakan simpanan karbon yang penting. Simpanan karbon ini tersimpan jauh di dalam perut bumi dan secara alami terpisah dari siklus karbon di atmosfer, kecuali apabila simpanan tersebut di ambil dan dilepaskan ke atmosfer ketika bahan-bahan tersebut dibakar. Semua pelepasan karbon dari simpanan ini akan menambah karbon yang berada di kantong karbon aktif (activecarbon pool). Saat ini yang terjadi selain kerusakan hutan, yaitu laju pembakaran bahan bakar fosil yang tinggi sehingga meningkatkan jumlah karbon yang berada di atmosfer. Proses fotosintesis dan penyimpanannya dalam jaringan tumbuhan pada tanaman akan mengurangi karbon di atmosfer $\left(\mathrm{CO}_{2}\right)$. Karbon tersebut akan menempati salah satu dari sejumlah kantong karbon sampai karbon tersebut tersikluskan kembali ke atmosfer.komponen penyusun dari biomassa di atas permukaan yaitu vegetasi baik pohon, semak, liana dan epifit. Sedangkan di bawah permukaan tanah, akar tumbuhan juga merupakan penyimpan karbon selain tanah itu sendiri.

\section{Pendekatan Penelitian}

\section{METODE PENELITIAN}

Pendekatan penelitian yang digunakan dalam penelitian ini adalah dengan analisis survei eksploratif (exploratory research).Nazir (2005) menjelaskan bahwa metode survei eksploratif sering digunakan untuk mengungkapkan fakta dan mengidentifikasi permasalahan serta mendapatkan pembenaran terhadap pelaksanaan yang sedang berjalan.Sejalan dengan pernyataan tersebut, maka penelitian ini memiliki tujuan untuk menjelaskan fakta berkembangnya usaha tani buah-buahan yang memiliki potensi komoditas di Kabupaten Tuban.

\section{Lokasi dan Waktu Penelitian}

Penelitian ini dilakukan di Kabupaten Tuban Provinsi Jawa Timur. Penentuan lokasi penelitian dilakukan secara sengaja, dengan mempertimbangkan daerah ini yang memiliki potensi besar dalam sektor pertanian baik dalam sektor pemanfaatannya maupun untuk pengembangannya yang akan mampu memberikan pengaruh yang tinggi pada peningkatan pertumbuhan ekonomi daerah di masa yang akan datang.

Penelitian ini dilakukan di Kabupaten Tuban dengan mengambil fokus area kawasan usaha tani buah-buahan.Lokasi penelitian diambil contoh (sample) secara sengaja yaitu 6 (enam) kecamatan.Lokasi ini dipilih karena keenam wilayah ini terdapat merupakan wilayah pengembangan usaha tani buah-buahan khususnya belimbing, jambu biji merah, mangga dan jeruk.Jumlah petani yang menjalankan usaha tani di enam kecamatan tersebut juga cukup banyak. Selain itu, lokasi dipilih berdasarkan kemudahan akses memasuki wilayah tersebut. Penelitian ini dilaksanakan sejak bulan April hingga November tahun 2015.

\section{Populasi dan Sampel Penelitian}

Populasi dalam penelitian ini adalah petani usaha tani buah-buahan yang berada di 6 (enam) kecamatan yang terdapat di Kabupaten Tuban, yaitu Kecamatan Palang, Kecamatan Soko, Kecamatan Tambakboyo, Kecamatan Kerek, Kecamatan Singgahan dan Kecamatan Grabagan. Jumlah petani buah-buahan dari 6 (enam) kecamatan adalah 166 petani yang bertani buah belimbing, jambu biji merah, mangga dan jeruk Berdasarkan jumlah petani sebagai unit populasi tersebut, maka diperlukan pengambilan 
sampel untuk mempermudah dalam pelaksanaan penelitian ini. Selain itu, alasan dilakukan pengambilan sampel bertujuan untuk dapat memahami tentang sifat dan karakterisasi petani buah-buahan, sehingga peneliti dapat dengan mudah menarik kesimpulan yang dapat digeneralisasikan terhadap populasi penelitian. Hal ini sejalan dengan Sekaran (2006) yang menjelaskan bahwa pengambilan sampel dapat dilakukan terhadap sebagian populasi, dikarenakan besarnya ukuran populasi dan beberapa faktor penghalang seperti faktor biaya, waktu, sumberdaya manusia, dan lain sebagainya.

Berdasarkan penjelasan tersebut, sampel yang diambil harus melalui prosedur yang representatif, yang berkaitan dengan dua aspek penting yaitu akurasi dan presisi. Sampel dapat dikatakan akurat, apabila statistik sampel dapat memprediksi parameter populasi dengan tepat, sedangkan sampel memiliki aspek presisi apabila mampu mencerminkan realitas populasi dengan cermat. Pada penelitian ini digunakan Metode Slovin untuk menentukan ukuran sampel. Metode Slovin yang digunakan pada penelitian ini dengan presisi 15\% dengan perhitungan menurut Siegel (1990) dan Setiawan (2007) sebagai berikut.

Keterangan:

$$
n=\frac{N}{1+N(e)^{2}}
$$

$\mathrm{n}=$ Jumlah sampel petani buah-buahan.

$\mathrm{N}=\quad$ Jumlah populasi petani buah-buahan.

$\mathrm{e}=$ Tingkat kesalahan $15 \%$.

Pada penelitian ini jumlah sampel setiap desa ditentukan dengan cara propotional sampling, dengan perhitungan berdasarkan rumus (Siegel, 1990; Santoso dan Tjiptono, 2002):

Keterangan:

$$
n_{i}=\frac{N_{i}}{N} n
$$

$\mathrm{n}_{\mathrm{i}}=\quad$ Jumlah sampel pada masing-masing kecamatan.

$\mathrm{N}_{\mathrm{i}}=\quad$ Jumlah populasi pada masing-masing kecamatan

$\mathrm{n}=$ Jumlah sampel.

Berdasarkan hasil perhitungan didapatkan jumlah sampel penelitian sebesar 166 orang petani buah-buahan khusunya belimbing, jambu biji merah, mangga dan jeruk sebagai informan kunci (key-informant).

\section{Metode Pengumpulan Data}

Data primer yang dibutuhkan pada penelitian ini antara lain yaitu: a) Data variabel fisik lahan dan manajemen usaha tani buah-buahan. Data ini merupakan data yang diperoleh dengan menggunakan metode survei langsung di lapangan dan wawancara sedangkan pengambilan data sampel tanah di beberapa titik lokasi perkebunan buahbuahan diperoleh dari dinas pertanian; b) Data total variabel pendapatan, variabel biaya tetap, variabel biaya tidak tetap, modal dan lain-lain yang diperlukan dalam usaha tani buah-buahan diperoleh dengan menggunakan metode survei dengan kuesioner yang disebar pada 166 responden yaitu petani buah yang terletak di 6 lokasi kecamatan; c) Optimalisasi pengolahan pengembangan usaha tani buah-buahan diperoleh dari data hasil survei dengan kuesioner sebelumnya. Data yang digunakan merupakan semua data yang telah dianalisis sebelumnya; d) Strategi pengolahan pengembangan usaha tani buahbuahan diperoleh dari hasil analisis kualitatif dan kuantitatif sebelumnya.

Data sekunder yang digunakan dalam penelitian ini merupakan data yang berasal dari beberapa sumber dokumen yang meliputi: data-data yang relevan dengan penelitian ini, termasuk juga penelitian-penelitian terdahulu yang relevan dengan penelitian ini. Data sekunder diperoleh dari Badan Pusat Statistik (BPS) Kabupaten Tuban (data luas lahan, curah hujan, hasil produksi buah-buahan dan lain-lain), Dinas Pertanian, Bappeda, 
Balai Penelitian, Dinas Tanaman Pangan dan Peternakan, Dinas Hutbun, Dinas Kelautan dan Perikanan, Kantor Desa (jumlah penduduk dan data pelengkap lainnya) dan dinas atau instansi lain di Kabupaten Tuban. Rentang waktu data sekunder yang digunakan adalah 6 tahun, yaitu antara tahun 2010-2015. Data lain yang digunakan adalah data jumlah produksi komoditas subsektor pertanian di Kabupaten Tuban Tahun 2010-2014 dan harga komoditas subsektor pertanian tingkat produsen di Kabupaten Tuban Tahun 2010-2014. Data letak geografis dan topografi, data kependudukan, data keadaan pertanian serta data Rencana Pembangunan Jangka Menengah Daerah (RPJMD) Kabupaten Tuban 2011-2016 merupakan data pendukung lainnya.

\section{Variabel dan Sumber Data}

Variabel dan sumber data yang dugunakan dalam penelitian ini disesuaikan dengan masalah dan tujuan penelitian yang akan dicapai. Adapun variabel yang diamati untuk mendapatkan kesesuaiaan lahan antara lain variabel fisik lahan usaha tani yang meliputi ketinggian, kelerengan, tekstur tanah, kedalaman tanah, jenis tanah, kemampuan lahan, dan iklim. Sedangkan untuk variabel manajemen budidaya yang meliputi pembibitan, penanaman, varietas tanaman buah-buahan, umur tanaman buah-buahan, pemupukan, pemeliharaan tanaman serta pemanenan buah.

Berdasarkan permasalahan yang ingin diselesaikan, salah satu variabel yang diamati adalah kelayakan ekonomi usaha tani buah-buahan dengan menggunakan perhitungan BEP Unit, BEP rupiah, R/C Ratio, B/C Ratio, NPV dan IRR yaitu dengan mengetahui pendapatan baik penerimaan maupun laba yang diperoleh petani buah, pengeluaran berupa variabel biaya tetap maupun variabel biaya tidak tetap dan juga modal. Data yang digunakan dalam penelitian ini diperoleh berdasarkan hasil survei dengan metode kuesioner yang diberikan kepada para petani dengan jumlah sampel tertentu. Sedangkan pada perhitungan optimalisasi digunakan metode goal programming dengan variabel kesesuaian lahan, kelayakan ekonomi usaha tani, produktivitas hasil panen buah-buahan, Biomassa Karbon, luas lahan, pendapatan petani buah-buahan, penyerapan tenaga kerja, biaya pengolahan usaha tani dan modal yang digunakan usaha tani. Selanjutnya dilakukan analisis sensitivitas dari hasil yang telah diperoleh. Setelah didapatkan variabel-variabel yang optimal berdasarkan hasil yang telah diperoleh sebelumnya, dilakukan analisis cluster yang memuat tiga aspek yaitu lingkungan, sosial dan ekonomi dari 6 kecamatan yang terdapat di Kabupaten Tuban.

Tabel 1. Variabel dan Sumber Data

\begin{tabular}{|c|c|c|c|}
\hline Masalah Penelitian & Variabel & $\begin{array}{c}\text { Teknik } \\
\text { Pengumpulan Data }\end{array}$ & Sumber Data \\
\hline $\begin{array}{l}\text { Bagaimana kelayakan } \\
\text { lingkungan pada } \\
\text { pengembangan potensi } \\
\text { komoditas unggulan } \\
\text { buah-buahan yang ramah } \\
\text { lingkungan khususnya } \\
\text { buah belimbing, jambu } \\
\text { biji merah, manga dan } \\
\text { jeruk di Kabupaten } \\
\text { Tuban }\end{array}$ & $\begin{array}{l}\text { Biomassa Karbon yang } \\
\text { terbentung pada usaha } \\
\text { tani buah-buahan } \\
\text { unggulan yang ramah } \\
\text { lingkungan }\end{array}$ & $\begin{array}{ll}- & \text { Pengamatan } \\
& \text { langsung di } \\
& \text { lapangan } \\
- & \text { Survei } \\
\text { menggunakan } \\
& \text { kuesioner } \\
- & \text { Wawancara } \\
& \text { terstruktur } \\
- & \text { Survei lapangan } \\
- & \text { Observasi }\end{array}$ & $\begin{array}{l}\text { - Petani buah- } \\
\text { buahan seperti } \\
\text { belimbing, } \\
\text { jambu biji } \\
\text { merah, mangga } \\
\text { dan jeruk }\end{array}$ \\
\hline
\end{tabular}

\section{Metode Analisis Data}

\section{Analisis Location Quotient (LQ)}

Salah satu analisis kuantitatif yang dapat digunakan untuk menentukan komoditi unggulan adalah analisis struktur ekonomi daerah dengan menggunakan pendekatan Location Quotient (LQ). Metode Location Quotient (LQ) adalah suatu pendekatan tidak langsung untuk mengetahui apakah suatu komoditi merupakan komoditi basis atau non basis. Keunggulan metode ini dalam mengidentifikasi komoditi unggulan antara lain 
penerapannya yang sederhana, mudah dan tidak membutuhkan program pengolahan data yang rumit. Penyelesaian analisisnya cukup dengan menggunakan perangkat lunak spread sheet dari MS Excel. Sebaik apapun hasil olahan metode LQ, tidak akan bermanfaat jika data yang digunakan tidak valid. Validitas atau kesahihan data dapat menghindari bias musiman dan tahunan. Sehingga diperlukan data runtun waktu (time serries) yang cukup panjang. Data yang dianalisis sebaiknya tidak kurang dari 5 tahun. Sementara itu, mengumpulkan data yang lengkap sepanjang 5 tahun tersebut sering mengalami hambatan di lapangan (Hendayana, 2003).

Pendekatan LQ mempunyai dua keunggulan yaitu sebagai berikut: a) Memperhitungkan ekspor, baik secara langsung maupun tidak lansung (barang antara), b) Metode ini tidak mahal dan dapat diterapkan pada data distrik untuk mengetahui kecendrungan. Kelebihan analisis LQ yang lainnya yaitu analisis ini dapat dibuat menarik jika dilakukan dalam bentuk time series/trend, artinya dianalisis selama kurun waktu tertentu. Analisis Location Quotient ( $L Q)$ juga dapat menentukan sektor dan sub sektor serta komoditi unggulan suatu perekonomian wilayah. Sektor, sub sektor, dan komoditi unggulan yang berkembang dengan baik mempunyai pengaruh yang signifikan terhadap pertumbuhan ekonomi suatu wilayah, yang pada akhirnya dapat meningkatkan pendapatan daerah secara optimal. Berikut rumus LQ yang digunakan dalam penelitian ini :

Dimana,

$$
L Q=\frac{p i / p t}{P i / P t}
$$

$L Q=\quad$ Location Quotient

$p i=$ Rata-rata produksi selama $t$ tahun jenis komoditas $i$ pada tingkat Kabupaten

$p t=$ Jumlah rata-rata produksi selama $t$ tahun semua komoditas $j$ pada tingkat Kabupaten

$P i=$ Rata-rata produksi selama $t$ tahun jenis komoditas $i$ pada tingkat Provinsi

$P t=$ Jumlah rata-rata produksi selama $t$ tahun semua komoditas $j$ pada tingkat

Provinsi

LQ>1 menunjukkan terdapat konsentrasi relative disuatu wilayah dibandingkan dengan keseluruhan wilayah. Hal ini berarti komoditas i disuatu wilayah merupakan sektor basis yang berarti komoditas i di wilayah itu memiliki keunggulam komparatif.LQ $=1$ merupakan sektor non basis, artinya komoditas i disuatu wilayah tidak memiliki keunggulan komparatif. produksi komoditas yang dihasilkan hanya cukup untuk memenuhi kebutuhan sendiri dalam wilayah itu.LQ $<1$.merupakan sektor non basis, artinya komoditas i disuatu wilayah tidak memiliki keunggulan komparatif, produksi komoditas i di wilayah itu tidak dapat memenuhi kebutuhan sendiri dan harus mendapat pasokan dari luar wilayah. Komoditas yang menghasilkan nilai LQ > 1 merupakan strandar normative untuk ditetapkan sebagai komoditas unggulan. Dan jika banyak komoditas yang menghasilkan nilai LQ $>1$ maka derajat keunggulan komparatif ditentukan berdasarkan nilai LQ yang lebih tinggi di suatu wilayah, karena semakin tinggi nilai LQ maka menunjukkan semakin tinggi pula potensi keunggulan komoditas tersebut (Muhammad, 2005).

\section{Metode Perhitungan Biomassa, Kandungan dan Serapan Karbon}

Jenis vegetasi yang mampu menyerap karbon paling tinggi yaitu jenis vegetasi berkayu. Dahlan (2004) dalam Ginoga (2004) memaparkan bahwa jenis vegetasi berkayu yang memiliki daya tumbuh cepat mampu menyerap karbon lebih tinggi dibandingkan dengan vegetasi yang memiliki daya tumbuh lambat, tetapi vegetasi yang lebih cepat tumbuh sebagian besar mempunyai tingkat kesulitan yang cukup tinggi dalam pengukuran pendugaan potensi serapan karbon yang ada dalam vegetasi itu, hal ini dikarenakan oleh bentuk batang yang relatif kurang silindris dan akar yang meluas, 
sehingga penggunaan metode yang digunakan berbeda-beda berdasarkan jenis vegetasi tersebut. Hal yang paling penting untuk mengetahui potensi serapan karbon dalam suatu kawasan hutan maka menggunakan metode pengukuran karbon, dengan memakai metode yang efektif dan benar maka potensi pengukuran karbon dapat diketahui secara tepat dan akurat. Rumus allometrik untuk menaksir biomassa pohon berdasarkan zona iklimnya (Chave et al., 2005).

Tabel 2. Rumus Allometrik Biomassa Karbon

\begin{tabular}{|c|c|}
\hline Curah hujan (mm/tahun) & Rumus allometrik \\
\hline \multirow[t]{3}{*}{ Kering $(<1500)$} & 1. $(\mathrm{AGB})_{\mathrm{est}}=0.112\left(\pi \mathrm{D}^{2} \mathrm{H}\right)^{0.916}$ \\
\hline & 2. $(\mathrm{AGB})_{\mathrm{est}}=\pi * \exp (-0.667+1.784 \ln (\mathrm{D})+0.207$ \\
\hline & $\left.(\ln (\mathrm{D}))^{2}-0.0281(\ln (\mathrm{D}))^{3}\right)$ \\
\hline \multirow{3}{*}{ Humid/Lembab (1500-4000) } & 1. $(\mathrm{AGB})_{\mathrm{est}}=0.0509 \times \pi \mathrm{D}^{2} \mathrm{H}$ \\
\hline & 2. $(\mathrm{AGB})_{\mathrm{est}}=\pi * \exp (-1.499+2.148 \ln (\mathrm{D})+0.207$ \\
\hline & $\left.(\ln (\mathrm{D}))^{2}-0.0281(\ln (\mathrm{D}))^{3}\right)$ \\
\hline \multirow[t]{3}{*}{ Basah $(>4000)$} & 1. $(\mathrm{AGB})_{\mathrm{est}}=0.0776 *\left(\pi \mathrm{D}^{2} \mathrm{H}\right)^{0.94}$ \\
\hline & 2. $(\mathrm{AGB})_{\mathrm{est}}=\pi * \exp (-1.239+1.980 \ln (\mathrm{D})+0.207$ \\
\hline & $\left.(\ln (\mathrm{D}))^{2}-0.0281(\ln (\mathrm{D}))^{3}\right)$ \\
\hline
\end{tabular}

Keterangan: $(A G B)$ est $=$ biomasa pohon bagian atas tanah, $\mathrm{kg} /$ pohon; $D=D B H$, diameter batang setinggi dada, $\mathrm{cm} ; H=$ tinggi pohon, $m ; \pi=B J \mathrm{kayu}, \mathrm{g} / \mathrm{cm}$ Persamaan no.1 digunakan apabila memiliki data tinggi dan diameter pohon; Persamaan no. 2 digunakan apabila hanya memiliki data diameter pohon

Berikut merupakan cara penentuan titik pengukuran DBH batang pohon bergelombang atau bercabang rendah berdasarkan Weyerhaeuser dan Tennigkeit, 2000 dalam Hairiah et al., 2011.

Keterangan:

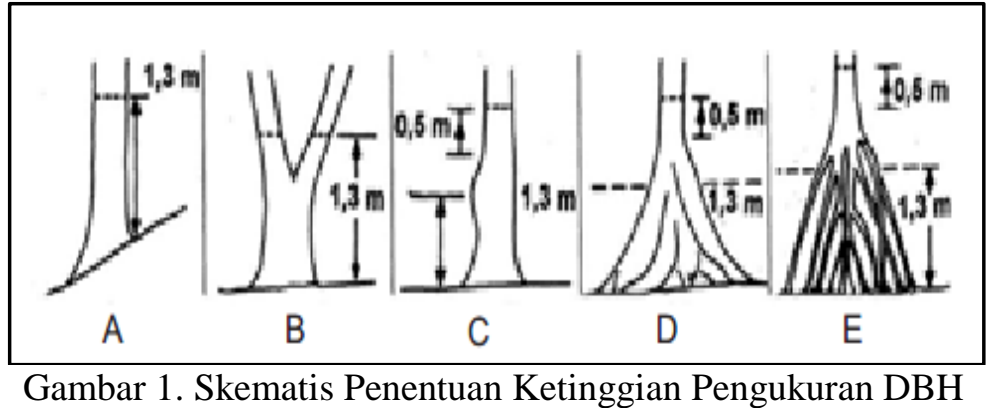

a. Pohon pada lahan berlereng, letakkan ujung tongkat $1.3 \mathrm{~m}$ pada lereng bagian atas

b. Pohon bercabang sebelum ketinggian $1.3 \mathrm{~m}$, maka ukurlah DBH semua cabang yang ada

c. Bila pada ketinggian $1.3 \mathrm{~m}$ terdapat benjolan, maka lakukanlah pengukuran DBH pada $0.5 \mathrm{~m}$ setelah benjolan

d. Bila pada ketinggian $1.3 \mathrm{~m}$ terdapat banir (batas akar papan) maka lakukan pengukuran DBH pada $0.5 \mathrm{~m}$ setelah banir. Namun bila banir tersebut mencapai ketinggian $>3 \mathrm{~m}$, maka diameter batang diestimasi

Selanjutnya kandungan karbon diduga dengan mengalikan biomassa dengan faktor konversi yang dikemukakan oleh (Murdiarso et al., 2002) sebagai berikut:

$$
C=0,5 B
$$

Dimana $C$ adalah kandungan karbon $(\mathrm{kg})$ dan $B$ adalah biomassa pohon kering $(\mathrm{kg})$ (setengah dari biomassa adalah kandungan karbon). Sedangkan besarnya penyerapan $\mathrm{CO}_{2}$ oleh tanaman yaitu dengan menggunakan rumus (Rifyunando, 2011):

$$
\text { Serapan } \mathrm{CO}_{2}=\frac{\mathrm{MrCO}}{\mathrm{ArC}} \times \text { Kandungan } \mathrm{C}
$$

Dimana $\mathrm{Mr} \mathrm{CO}_{2}$ merupakan berat molekul senyawa (44) dan Ar C merupakan berat molekul relatif atom $\mathrm{C}(12)$. 


\section{HASIL DAN PEMBAHASAN}

\section{Potensi Komoditas Unggulan}

Komoditi unggulan di Kabupaten Tuban pada sektor pertanian salah satunya adalah pada buah-buahan. Luas lahan usaha tani yang dipergunakan untuk penanaman buahbuahan mencapai 55.229,844 Ha dan luas lahan pekarangan 15.524,075 Ha serta luas ladang $61.000 \mathrm{Ha}$. Hal ini memungkinkan untuk para petani dalam mengelola jenis buahbuahan yang dapat menopang pertumbuhan ekonominya. Meskipun wilayah yang terdapat di Kabupaten Tuban cenderung banyak yang terdapat di wilayah pesisir pantai, namun masih banyak lahan yang tersedia dan mampu digunakan dalam usaha tani khususnya buah-buahanan. Macam-macam buah-buahan yang menjadi ciri khas di Kabupaten Tuban antara lain yaitu siwalan, kawista, blimbing Tasikmadu dan duku Prunggahan. Kawista (Lemonia Acidissima Linn) sering dijumpai di Kecamatan Bancar yang ditanam secara tradisional di pekarangan rumah. kegunaan tanaman kawista antara lain daging buah segarnya dapat dimakan dengan mencampur gula atau sirup dan es krim. Duri dan kulit buahnya dapat digunakan sebagai pengobatan, sedangkan kayunya dapat dimanfaatkan untuk bangunan rumah dan peralatan pertanian.

Pada penelitian ini, peneliti ingin mengetahui sektor buah yang bisa memiliki potensi dalam menjadi komoditas unggulan selain buah yang saat ini menjadi ciri khas di Kabupaten Tuban. Berdasarkan survei di lapangan, hasil pertanian buah-buahan yang dikaji adalah buah belimbing, jambu biji merah, mangga dan jeruk. Lokasi yang digunakan untuk meneliti hasil pertanian buah-buahan tersebut sebanyak 6 kecamatan antara lain Kecamatan Palang, Soko, Tambakboyo, Kerek, Singgahan dan Grabagan. Dalam mengetahui potensi komoditas unggulan diantara buah-buahan tersebut, digunakan metode LocationQuotient (LQ). Metode ini menggunakan luas panen keempat tanaman yang menjadi buah yang menghasilkan di wilayah Kabupaten Tuban. Buah-buahan yang diteliti dalam penelitian ini antara lain belimbing, jambu biji merah, mangga dan jeruk. Skala waktu yang digunakan dalam penelitian ini adala produksi pertahun dalam ton yang dibandingkan dengan produksi yang ada pada wilayah Jawa Timur selama 6 tahun terakhir yaitu pada tahun 2010 hingga tahun 2015. Berdasarkan hasil perhitungan diperoleh nilai LQ sebagai berikut:

Tabel 3.Komoditi Basis Buah-buahan

\begin{tabular}{|c|l|c|c|}
\hline No & \multicolumn{1}{|c|}{ Luas Panen } & LQ & Status \\
\hline 1 & Belimbing & $\mathbf{2 , 3 5 9}$ & Basis \\
\hline 2 & Jambu Biji Merah & $\mathbf{1 , 3 0 9}$ & Basis \\
\hline 3 & Mangga & $\mathbf{1 , 5 3 6}$ & Basis \\
\hline 4 & Jeruk & 0,017 & Non Basis \\
\hline
\end{tabular}

Berdasarkan Tabel 3 terlihat bahwa buah belimbing memiliki potensi yang lebih unggul untuk dikembangkan. Setelah itu buah mangga dan jambu biji merah memiliki potensi menjadi salah satu buah yang memiliki keunggulan komoditi di Kabupaten Tuban. Mengacu pada hasil penelitian ini yang dilakukan dengan menggunakan data dari tahun 2010 hingga 2015, dapat dilakukan upaya untuk mengembangkan kawasan Kabupaten Tuban pada sektor buah-buahan.

\section{Karbon (C)}

Biomassa karbon merupakan kandungan karbon yang tersimpan pada permukaan tanah sebagai sisa tanaman yang sudah mati (nekromasa) dan biomassa tanaman maupun yang tersimpan dalam tanah sebagai bahan organik. Kemudian, perubahan wujud karbon ini dijadikan dasar untuk menghitung emisi, dimana sebagian besar unsur karbon (C) yang terurai ke udara biasanya terikat dengan $\mathrm{O}_{2}$ (oksigen) dan menjadi $\mathrm{CO}_{2}$ (karbondioksida). Maka dari itu, ketika satu hektar hutan menghilang (pohon-pohonnya mati), biomasa pohon-pohon tersebut lambat laun terurai dan unsur karbonnya akan terikat ke udara menjadi emisi. Akan terjadi proses pengikatan unsur $\mathrm{C}$ dari udara kembali menjadi biomassa tanaman secara bertahap ketika satu lahan kosong ditanami 
Kristiawan \& Maimunah, 2020. Kajian Karbon Pada Pengembangan Produk Unggulan BuahBuahan Ramah Lingkungan Di Kabupaten Tuban Jawa Timur.

Journal Viabel Pertanian. (2020), 14(1)76-90

tumbuhan dan tumbuhan tersebut tumbuh besar (sekuestrasi). Ukuran volume tanaman penyusun lahan tersebut kemudian menjadi ukuran jumlah karbon yang tersimpan sebagai biomasa (Biomassa karbon) (Kauffman dan Donato, 2012).

Penelitian mengenai karbon tersimpan perlu dilaksanakan untuk mengetahui perubahan karbon tersimpan di suatu kawasan akibat konversi penggunaan lahan. Konversi penggunaan lahan dapat dipantau dengan menggunakan teknologi penginderaan jauh. Perubahan karbon yang tersimpan di atas maupun di bawah permukaan suatu area dapat diketahui dengan menggunakan Integrasi data lapang dan data spasial perubahan penggunaan lahan. Jawaban atas tantangan peningkatan produksi pertanian yang semakin kompleks dengan langkah strategis yaitu mengembangkan lahan pertanian yang pasang surut. Dengan pengelolaan yang tepat melalui penerapan ilmu pengetahuan dan teknologi yang benar, pengembangan lahan pasang surut mempunyai prospek besar untuk menjadi lahan pertanian yang produktif terutama dalam rangka melestarikan swasembada pangan, diversifikasi produksi, peningkatan pendapatan dan lapangan kerja, serta pengembangan agribisnis dan wilayah (Abdurachman dan Ananto, 2000).

Buah-buahan merupakan sumber vitamin yang dibutuhkan dalam memenuhi gizi keluarga, disamping sebagai sumber pendapatan. Pada hasil penelitian Biomassa karbon yang terdapat di kabupaten Tuban, rata-rata Biomassa karbon pada komoditas buahbuahan belimbing, jambu biji merah, mangga dan jeruk dapat dilihat pada gambar diagram berikut:

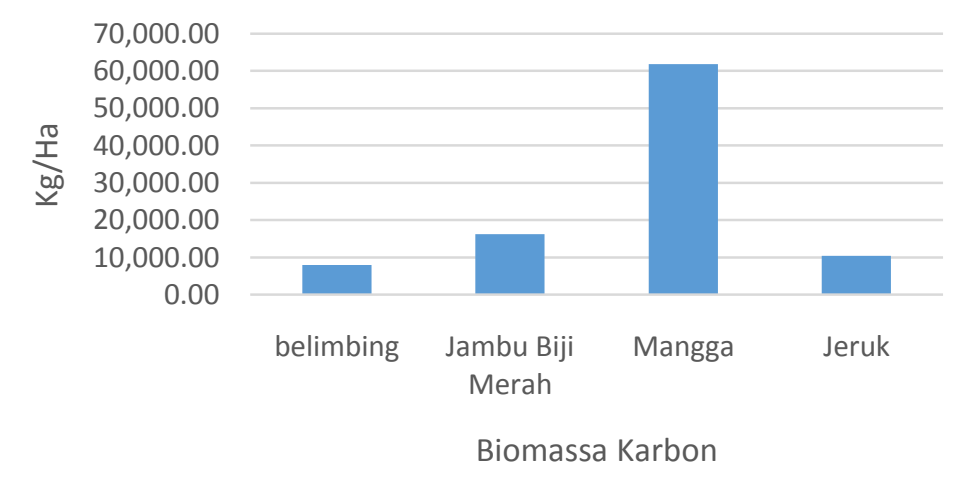

Gambar 2.Biomassa Karbon Komoditas Buah-Buahan di Kabupaten Tuban

Hasil penelitian berdasarkan jumlah wilayah sampel yang telah diteliti membuktikan bahwa pada lahan pertanian buah belimbing di kawasan Kabupaten Tuban memiliki biomassa karbon sebesar 7.888,18 Kg/Ha. Sedangkan pada lahan pertanian jambu biji merah memiliki biomassa karbon sebesar $16.184,47 \mathrm{Kg} / \mathrm{Ha}$. Pada lahan pertanian buah mangga memiliki biomassa karbon yang lebih besar yaitu sebesar $61.823,20 \mathrm{Kg} / \mathrm{Ha}$. Pada lahan pertanian buah jeruk memiliki biomassa karbon sebesar $10.399,29 \mathrm{Kg} / \mathrm{Ha}$. Berdasarkan hasil penelitian pada setiap hektar lahan usaha tani buahbuahan, secara rinci Biomassa karbon yang dimiliki oleh tanaman buah-buahan per hektar adalah sebagai berikut:

Tabel 4.Biomassa karbon Pada Tanaman Buah di Kabupaten Tuban

\begin{tabular}{|c|c|c|c|c|}
\hline Biomassa karbon & belimbing & Jambu Biji Merah & Mangga & Jeruk \\
\hline 1 pohon $(\mathrm{kg})$ & 39,44 & 40,46 & 618,23 & 26,00 \\
\hline 1 ha $(\mathrm{kg})$ & $7.888,18$ & $16.184,47$ & $61.823,20$ & $10.399,29$ \\
\hline
\end{tabular}

Berdasarkan hasil perhitungan Biomassa karbon, terlihat bahwa Biomassa karbon terbesar diperoleh dari tanaman buah mangga. Hal ini dikarenakan pada tanaman buah mangga memiliki batang yang lebih besar daripada tanaman komoditas lainnya seperti belimbing, jambu biji merah atau jeruk. Selain itu, tanaman komoditas mangga memiliki usia yang relatif lebih lama sehingga memiliki biomassa karbon yang relatif besar. Selain 
dipengaruhi oleh tanaman itu sendiri, biomassa karbon yang terbentuk dapat pula dipengaruhi oleh kualitas dalam pengelolaan lahan. Tanaman buah-buahan dalam merespon kondisi lingkungan lahan pada tempat tumbuhnya cukup sulit untuk dijelaskan terutama dalam hal kemampuan akar tanaman dalam menyerap nutrisi dan mineral yang terkandung dalam tanah. Pengelolaan tanah yang baik sangat penting untuk produktivitas tanaman.

Selain itu, pengelolaan $\mathrm{pH}$ tanah juga memilki kadar yang berbeda-beda di tiap wilayahnya. Tanah dapat diasamkan dengan menambahkan bahan organik atau belerang atau sulfat.Tanah dapat ditingkatkan $\mathrm{pH}$ nya dengan menambahkan kapur atau abu kayu. Namun harus disesuaikan dengan kondisi tanah pada kebutuhan tanaman buah itu sendiri. Tiga unsur hara esensial, yaitu karbon, oksigen dan hidrogen, sangat penting untuk pertumbuhan tanaman dan disediakan oleh udara dan air.Unsur-unsur penting lainnya yang disebut sebagai nutrisi tanaman, disediakan olehtanah, atau ditambahkan sebagai pupuk, dan diserap tanaman secara eksklusif melalui akar.Nutrisi tanaman ini dibagi menjadi dua kelompok.Nutrisi yang dibutuhkanoleh tanaman dalam jumlah besar disebut hara makro; yaitu nitrogen, fosfor, kalium, kalsium, magnesium dan sulfur. Unsur hara yang lain disebut hara mikro; termasuk besi, klorin, seng, molibdenum, boron, mangan, tembaga, sodium dan kobalt. Makro nutrien dan mikro nutrien semuanya penting untuk pertumbuhan tanaman normal dan perkembangannya; mereka dibutuhkan dalam jumlah yang berbeda-beda.

Lahan usaha tani juga memerlukan adanya sumber pupuk organik yang berupa kompos, pupuk kandang dan pupuk hijau. Pupuk organik dapat "ditanam" bersama dengan menanam tanaman penutup tanah, yang merupakan tanaman yang ditanam untuk dibenamkan ke dalam tanah, biasanya disebut pupuk hijau.Tanaman penutup tanah juga menambahkan bahan organik ke tanah.Produk pupuk anorganik juga banyak tersedia, baik sebagai produk single-hara atau multi-nutrisi.Pupuk dapat diberi label sebagai "slow release" atau "pupuk larut". Pupuk "slow-release" melepaskan nutrisi tersedia selama periode waktu yang panjang."Pupuk larut" melepaskan hara tersedia secara cepat,dan banyak yang larut dalam air dan tersedia bagi tanaman.

Nutrisi dapat disediakan oleh banyak produk pupuk dan praktek pemupukan.Harga pupuk, ketersediaan, kemudahan penggunaan, peralatan yang dibutuhkan, waktudan filsafat pemupukannya semua memainkan perandalam memilih jenis pupuk dan metode aplikasi yang terbaik untuk setiap situasi.Kadang-kadang, dalam situasi kekurangan hara yang parah, beberapa hara mikro dapat disemprotkan ke daun tanaman.Dalam sistem produksi hidroponik, nutrisi yang dilarutkan dalam air dapat diserap akar tanaman.Sebagian besar tanah mengandung sejumlah hara.Hanya uji tanah yang dapat menilai ketersediaan hara ini.Pemupukan yang dilakukan tanpa hasil uji tanah menyebabkan pemborosan uang dan produk, dan dapat memperburuk ketidakseimbangan nutrisi yang ada.Selain itu, kadang-kadang nutrisi yang hadir dalam pasokan cukup tetapi tidak tersedia karena $\mathrm{pH}$ yang terlalu tinggi atau terlalu rendah.Uji tanah dapat mengungkapkan hal ini, dan laboratorium tanah profesional atau konsultan tanaman dapat merekomendasikan penyelesaian masalah tersebut.

Sedangkan hasil perhitungan kandungan karbon yang dimiliki oleh tanaman buahbuahan di Kabupaten Tuban adalah sebagai berikut:

Tabel 5.Kandungan karbon Pada Tanaman Buah di Kabupaten Tuban

\begin{tabular}{|c|c|c|c|c|}
\hline Kandungan karbon & belimbing & Jambu Biji Merah & Mangga & Jeruk \\
\hline 1 pohon $(\mathrm{kg})$ & 19,72 & 20,23 & 309,12 & 13,00 \\
\hline 1 ha $(\mathrm{kg})$ & $3.944,09$ & $8.092,24$ & $30.911,60$ & $5.199,64$ \\
\hline
\end{tabular}

Berdasarkan hasil perhitungan pada Tabel 5 terlihat bahwa mangga merupakan tanaman yang memiliki kandungan karbon terbanyak daripada tanaman buah lainnya. Hal ini disebabkan bahwa tanaman mangga merupakan tanaman yang memiliki ciri fisik terbesar serta memiliki usia yang relatif lebih lama daripada tanaman belimbing, jambu 
biji merah atau jeruk. Pada penelitian ini juga tertera hasil perhitungan serapan $\mathrm{CO}_{2}$ yang dapat diserap oleh tanaman buah-buahan tersebut:

Tabel 6.Serapan $\mathrm{CO}_{2}$ Pada Tanaman Buah di Kabupaten Tuban

\begin{tabular}{|c|c|c|c|c|}
\hline Serapan $\mathbf{C O}_{\mathbf{2}}$ & belimbing & Jambu Biji Merah & Mangga & Jeruk \\
\hline 1 pohon $(\mathrm{kg})$ & 72,31 & 74,18 & 1133,43 & 47,66 \\
\hline 1 ha $(\mathrm{kg})$ & $14.461,67$ & $29.671,53$ & $113.342,53$ & $19.065,36$ \\
\hline
\end{tabular}

Berdasarkan hasil perhitungan pada Tabel 6.10 mengenai serapan karbon, secara berturut-turut tanaman buah mangga merupakan yang memiliki biomassa karbon, kandungan karbon dan serapan $\mathrm{CO}_{2}$ tertinggi daripada tanaman buah lainnya dalam penelitian ini.

\section{KESIMPULAN}

Berdasarkan hasil penelitian yang dilakukan pada 6 kecamatan di wilayah Kabupaten Tuban dengan menggunakan metode Location Quotient (LQ), buah belimbing memiliki potensi yang lebih unggul untuk dikembangkan. Setelah itu buah mangga dan jambu biji merah memiliki potensi menjadi salah satu buah yang memiliki keunggulan komoditi. Hasil penelitian ini yang dilakukan dengan menggunakan data dari tahun 2010 hingga 2015, dapat dilakukan upaya untuk mengembangkan kawasan Kabupaten Tuban pada sektor buah-buahan. Hal ini dapat dijadikan sebagai suatu kebijakan pemerintah Kabupaten Tuban yang bertujuan untuk mensejahterakan masyarakat sekitar khususnya petani buah tersebut. Kabupaten Tuban memiliki lokasi yang dekat dengan pantai, maka kawasan ini mempunyai lanscape yang indah yang berpotensi sebagai pengembangan wisata atau dengan kata lain wisata petik buah.

Berdasarkan hasil perhitungan biomassa karbon, biomassa karbon terbesar diperoleh dari tanaman buah mangga yaitu sebesar $61.823,20 \mathrm{Kg} / \mathrm{Ha}$. Hal ini dikarenakan pada tanaman buah mangga memiliki batang yang lebih besar daripada tanaman komoditas lainnya seperti belimbing, jambu biji merah atau jeruk. Selain itu, tanaman komoditas mangga memiliki usia yang relatif lama sehingga memiliki biomassa karbon yang relatif besar. Selain dipengaruhi oleh tanaman itu sendiri, biomassa karbon yang terbentuk dapat pula dipengaruhi oleh kualitas dalam pengelolaan lahan. Tanaman buahbuahan dalam merespon kondisi lingkungan lahan pada tempat tumbuhnya cukup sulit untuk dijelaskan terutama dalam hal kemampuan akar tanaman dalam menyerap nutrisi dan mineral yang terkandung dalam tanah. Pengelolaan tanah yang baik sangat penting untuk produktivitas tanaman. Manajemen yang baik harus mencakup pertimbangan menjaga integritas tanah dari waktu ke waktu.Manajemen yang buruk dapat menyebabkan erosi, hilangnya kesuburan, kerusakan struktur tanahdan hasil panen yang buruk.

\section{DAFTAR PUSTAKA}

Abdurrachman dan Ananto E.E. 2000. Konsep Pengembangan Pertanian Berkelanjutan Di Lahan Rawa Untuk Mendukung Ketahanan Pangan dan Pengembangan Agribisnis.Seminar Nasional Penelitian dan Pengembangan Pertanian di Lahan Rawa.Bogor, 25-27 Juli 2000.23 halaman.

Bappenas (Badan Perencanaan Pembangunan Nasional), 2006, Petunjuk Teknis Pengajuan Usulan Kegiatan Yang Dibiayai Dari Pinjaman Dan/Atau Hibah Luar Negeri, Jakarta.

Brown S. 1997. Estimating Biomass and Biomass Change of Tropical Forest.A Primer.FAO. USA. FAO Forestry Paper No.134.

Chave J, Andalo C, Brown S, Cairns MA, Chambers JQ, Eamus D, Folster H, Fromard F, Higuchi N, Kira T, Lescure JP, Nelson BW, Ogawa H, Puig H, Riera B and Yamakura T. 2005. Tree Allometry And Improved Estimation Of Carbon Stocks 
And Balance In Tropical Forests. Oecologia 145 (87). DOI 10.1007/s00442-0050100-x.

Clark, A.I. 1979. Suggested Procedures for Measuring Tree Biomass and Reporting Tree Prediction Equations. Forest Resource Inventories 2 (615). Colorado State University: Fort Collins, Co.

Donato, D. C., Kauffman, B., dan Murdiyarso D. 2012.Mangrove adalah Salah SatuHutan Terkaya Karbon di Kawasan Tropis.Center for International Forest Research. Bogor.

Eko Sri Meiningsih. 2010. Analisis Komoditi Unggulan Sektor Pertanian Kabupaten Sukoharjo Sebelum Dan Selama Otonomi Daerah. Thesis Pasca Sarjana. Program Studi Magister Ekonomi dan Studi Pembangunan. UNS. Surakarta.

FWI dan GFW.2001. Potret Keadaan Hutan Indonesia. Bogor. Indonesia: Forest Watch Indonesiadan Washington D.C: Global Forest Watch.

Fardiaz, S. 1995. Pengembangan Industri Pengolahan Hasil Perikanan di Indonesia, Tantangan dan Harapan Sistem Jaminan Mutu. Buletin Teknologi dan Industri Pangan. 1: 65-73.

Hairiah K, Sitompul SM, van Noordwijk M. and Palm, C. 2001. Carbon Stocks of tropical landuse systems as part of the global $\mathrm{C}$ balance: effects of forest conversion and option for clean development activities. ASB Lecture Note 4A. ICRAF, Bogor, 49pp.

Ginoga K. 2004. Beberapa Cara perhitungan Biomassa karbon.Jurnal Sosial Ekonomi IV.Badan Penelitian Pengembangan Kehutanan Bogor.

Hairiah. 2001. Carbon Stocks of Tropical Land Use Systems as Part of theGlobal CBalance: Effects of Forest Conversion and Options for 'CleanDevelopment' Activities. International Centre for Research in AgroforestrySoutheast Asian Regional Research Programme. Bogor.

Huseini, Martani. 1999. Mencermati Misteri Globalisasi: Menata Ulang Strategi Pemasaran Internasional Indonesia Melalui Pendekatan Resource - Based, FISIP UI, Jakarta.

Kusmana C., Sabiham, S., Abe, K., \& Watanabe, H. 1992. An Estimation of Above Ground Tree Biomass Of A Mangrove Forest in East Sumatera, Indonesia. Tropics 1 (4): 243-257.

Mc William, A.L.C. J.M, Roberts, O.M.R, Cabral. M.V.B.R, Leitao.A.C.L, De Costa.G.T, Maitelli.C.A.G.P, Zamparoni. 1993. Leaf Area Index and AboveGround Biomass of Terra Firme Rain Forest and Adjacent Clearings in Amazonia. Functional Ecology Vol.7. Hlm:310-317.

Moh.Nazir. Ph.D. 2005. Metode Penelitian. Ghalia Indonesia. Bogor.

Restiatun. 2009. Identifikasi Sektor Unggulan Dan Ketimpangan Antar Kabupaten/Kota Di Provinsi DIY. Jurnal Ekonomi dan Studi Pembangunan Volume 10, Nomor 1, 77 - 98. Yogyakarta.

Whitmore, T.C. 1985. Tropical Rain Forests of the Far East.Oxford: Clarendon. 